\title{
PMEL Gene
}

National Cancer Institute

\section{Source}

National Cancer Institute. PMEL Gene. NCI Thesaurus. Code C41033.

This gene plays a role in melanosome biogenesis. It is also involved in T-cell recognition. 